\title{
Effects of Infectious Bursal Disease Vaccination Strains on the Immune System of Leghorn Chickens
}

\author{
L. KULÍKOVÁ, V. JURAJDA, R. JURANOVÁ \\ Avian and Exotic Animal Clinic \\ University of Veterinary and Pharmaceutical Science, Brno, Czech Republic
}

Received December 15, 2003

Accepted June 17, 2004

\begin{abstract}
Kulíková L., V. Jurajda, R. Juranová: Effects of Infectious Bursal Disease Vaccination Strains on the Immune System of Leghorn Chickens. Acta Vet. Brno 2004, 73: 205-209.

The detection of infectious bursal disease on chicken farms in the Czech Republic and problems related with it triggered the interest in the immunoprophylaxis of the disease in this country. In the present study, levels of post-vaccination antibodies against infectious bursal disease were monitored by the ELISA test in seven experiments with Leghorn chickens free of maternal antibodies. The chickens were vaccinated with commercial vaccines made of viruses of different virulence (A, B, C-mild; D - intermediate; E, F, G - highly virulent). Effects of vaccination strains on the chickens' immune system were assessed using the bursa of Fabricius index, and a statistical comparison with results from a control group was made.

Of the mild vaccines, only vaccine A produced a sufficiently high antibody titre and $100 \%$ positivity in the group. Vaccine $\mathrm{C}$, on the other hand, caused a statistically significant $(p<0.05)$ atrophy of the bursa of Fabricius. The intermediate vaccine D produced only $80 \%$ positivity, with the lowest average post-vaccination antibodies titres and statistically insignificant BF index. The most virulent vaccines $\mathrm{E}$ and $\mathrm{F}$ demonstrated an almost $100 \%$ positivity, high post-vaccination antibodies titres and, as expected, statistically significant $(p<0.01)$ bursal atrophy. Vaccine $\mathrm{G}$ from among the virulent vaccines also produced $100 \%$ positivity, but, surprisingly, caused no damage to the bursa of Fabricius.

The results of the study point to differences in virulence and immunogenic properties of different vaccination strains within individual groups of vaccines that need to be borne in mind in everyday veterinary practice.
\end{abstract}

Bursa of Fabricius, immunoprophylaxis, ELISA, vaccines, chickens

Infectious bursal disease (IBD) is an acute and highly contagious viral disease affecting young chickens and is characterized by massive damage to the bursa of Fabricius (FB) and by immunosuppression (Lukert et al. 1997). The infectious bursal disease virus (IBDV) belongs to the family Birnaviridae (Brown 1986), and it consists of two segments of double-stranded RNA (Jackwood et al. 1984). There are two IBVD serotypes, but only one (serotype 1) is pathogenic for domestic fowl. The expression of serotype 1 pathogenicity, however, varies. While some infected chickens will not even show any clinical symptoms of the disease, other chickens may die: in specific pathogen free (SPF) chickens, IBD mortality ranges between $30 \%$ and $70 \%$ (Nunoy a et al. 1992).

The first clinical cases of IBD reported in the mid-1990s from the Czech Republic were preceded by reports of IBD from Slovakia (Pospíšilová 1999). Acute bursal diseases cases were mainly reported from commercial broiler chicken feeding farms and laying broiler pullet farms, and were rare in non-commercial flocks (Juranová et al. 2001).The basis for infectious bursal disease prevention is specific immunoprophylaxis. Inactivated oil vaccines and live apathogenic or attenuated vaccines of various virulence levels are used. There are three types of live vaccines: mild, intermediate (Lukert et al. 1997) and highly virulent. Intermediate vaccines can induce a higher level of immunogenicity in chickens than mild vaccines, but they may differ in virulence and some may even induce atrophy of 
the bursa of Fabricius in young chickens (Mazariegos et al. 1990). Virulent vaccines are suitable in areas with a highly pathogenic IBDV.

Lack of information on the characteristics of virulent strains makes the monitoring of incidence of the highly virulent IBD virus very difficult (Tsukamoto et al. 1995). The objective of the study presented here was to investigate the degree of virulence of vaccination strains, their inmmunogenicity, their effect on the function of FB and safety and efficacy of their use.

\section{Materials and Methods}

Chickens from a controlled striped Leghorn flock (Czech Academy of Sciences Prague, free of avian leukosis), were used in experiments. The parent flock was IBDV antibodies free. The chickens were housed in experimental units with a slatted floor and were given K1 feed mixture (Biosta s.r.o., Blučina) and water ad libitum.

The seven vaccines representing all the three types of vaccines were chosen at random. The vaccines designated A to $\mathrm{G}$ are commonly used vaccines in the Czech Republic. Mild vaccines were vaccines A (strain Z2037), B (strain OP 23) and C (strain D 78). The intermediate vaccine was vaccine D (strain S 706). Virulent vaccines included vaccines $\mathrm{E}$ (strain V 877), F (strain $228 \mathrm{E}$ ) and G (strain LC 75). Each commercial vaccine against IBDV was tested in a separate experiment.

After hatching, chickens were wing-tagged and housed together. Five out of each batch of 45 chickens were picked at random, bled and euthanized and tested for the level of IBD antibodies. The number of chickens for IBD antibodies tests was considered sufficient in view of their parents' negative IBDV antibodies titres. The remaining 40 chickens were equally divided into a test group and a control group, i.e. each group consisted of 20 chickens. Vaccines were administered in drinking water according to manufacturers' recommendations in chicken drinkers (100 vaccination doses per litre of water). At 10 and 17 days after vaccination, ten vaccinated and 5 control chickens from each group were weighed, euthanized and bled. The chickens were autopsied, blood samples were collected for serological tests and the bursa of Fabricius was removed and weighed.

Blood serum samples from test and control birds were stored in a freezer at $-20^{\circ} \mathrm{C}$ and subsequently tested using the commercial IDEXX - Infectious Bursal Disease Antibody Test Kit. Serum samples were tested for IBVD antibodies by the ELISA test. Serum samples with the $\mathrm{S}: \mathrm{P}$ ratio ( $\mathrm{S}=$ serum sample, $\mathrm{P}=$ positive control) less than or equal to 0.2 were considered negative. Ratios above 0.2 (titres higher than 396 ) were considered positive.

Vaccine efficacy was assessed on the basis of results of serologic assays (titres of post-vaccination antibodies and number of positive chickens) and the relative weight of the bursa of Fabricius calculated as the weight of the bursa of Fabricius (g) / weight of chicken $(\mathrm{g}) \times 1000$ (Lucio a Hitchner 1979).

Analytical methods of the Excel programme (Microsoft Office Professional, 2000) were used to statistically evaluate the results of experiments.

\section{Results}

Results of vaccine tests are summarized in Table 1. Pathological and anatomical examinations failed to reveal any macroscopic changes on internal organs or the bursa of Fabricius of the control and vaccinated chickens. No histopathological examination of the BF was performed.

In each experiment, five chickens were tested for IBD antibodies at 14 days of age before vaccination. Antibodies titres were considered negative in accordance with ELISA test guidelines.

Of the mild vaccines tested, vaccine $\mathrm{C}$ demonstrated higher pathogenicity for the $\mathrm{BF}(\mathrm{BF}$ index at day 10 post vaccination 2.35) than the remaining two mild vaccines $\mathrm{A}$ and $\mathrm{B}(\mathrm{BF}$ indices of 3.05 and 3.16 respectively at day 10 post vaccination). The intermediate vaccine $\mathrm{D}$, on the other hand, did not express its virulence (BF index of 2.94 at day 10 post vaccination). Vaccines $\mathrm{E}$ and $\mathrm{F}$ showed high pathogenicity for the bursa of Fabricius (BF indices 0.91 and 1.25 respectively at day 10 post vaccination), vaccine $G$ did not cause any atrophy to the bursa of Fabricius (BF index of 3.17 at day 10 post vaccination). Differences in vaccine virulence for the bursa of Fabricius at day 10 post vaccination were similar to those found at day 17 post vaccination.

Of mild vaccines, only vaccine A produced $100 \%$ positivity and sufficiently high titres at day 10 post vaccination. Highly virulent vaccines produced almost $100 \%$ positivity and high titres of post vaccination antibodies. Serum positivity of the birds tested at day 17 post vaccination was almost $100 \%$. The only exceptions were vaccines D (80\%) and E (90\%). 
Average antibodies titres were also higher, and were in the range from 1400 to 1800 in most of the vaccines tested. Higher titres were found in vaccines F (average titre of 2844) and G (average titre of 3586).

Table 1

Post-vaccination antibodies and the BF index following vaccination against IBDV

\begin{tabular}{|c|c|c|c|c|c|c|c|}
\hline \multirow{3}{*}{\multicolumn{2}{|c|}{ Group }} & \multicolumn{3}{|c|}{ day 10 after vaccination } & \multicolumn{3}{|c|}{ day 17 after vaccination } \\
\hline & & \multirow{2}{*}{ BF index } & \multicolumn{2}{|c|}{ ELISA } & \multirow[t]{2}{*}{ BF index } & \multicolumn{2}{|c|}{ ELISA } \\
\hline & & & pos. $\%$ & titre & & pos.\% & titre \\
\hline \multirow[t]{2}{*}{ A } & Test & 3.05 & 100 & 1210 & 3.89 & 100 & 1833 \\
\hline & Control & 3.96 & 0 & 45 & 3.86 & 0 & 21 \\
\hline \multirow[t]{2}{*}{ B } & Test & 3.16 & 80 & 596 & 3.78 & 100 & 1493 \\
\hline & Control & 3.29 & 0 & 62 & 3.83 & 0 & 156 \\
\hline \multirow[t]{2}{*}{$\mathrm{C}$} & Test & $2.35 * *$ & 80 & 709 & $2.65^{*}$ & 100 & 1580 \\
\hline & Control & 3.58 & 0 & 90 & 3.48 & 0 & 64 \\
\hline \multirow[t]{2}{*}{$\mathrm{D}$} & Test & 2.94 & 20 & 237 & 3.98 & 80 & 1451 \\
\hline & Control & 3.55 & 0 & 0 & 4.12 & 0 & 8 \\
\hline \multirow[t]{2}{*}{$\mathrm{E}$} & Test & $0.91 * *$ & 90 & 1209 & $1.67 * *$ & 90 & 1827 \\
\hline & Control & 3.13 & 0 & 77 & 3.64 & 0 & 51 \\
\hline \multirow[t]{2}{*}{ F } & Test & $1.25^{* *}$ & 100 & 2270 & $1.52 * *$ & 100 & 2844 \\
\hline & Control & 3.68 & 20 & 107 & 4.55 & 0 & 12 \\
\hline \multirow[t]{2}{*}{ G } & Test & 3.17 & 100 & 2631 & 3.27 & 100 & 3586 \\
\hline & Control & 3.11 & 0 & 3 & 3.77 & 0 & 4 \\
\hline
\end{tabular}

* Statistically significant difference from the control group at $p<0.05$

** Statistically significant difference from the control group at $p<0.01$

\section{Discussion}

Seven commercial vaccines against infectious bursal disease available in the Czech Republic were divided into groups according to the vaccination virus virulence as declared by manufacturer and tested in in vivo experiments on chickens free of IBD virus antibodies. The chickens were vaccinated at 14 days of age, and titres of post-vaccination antibodies, group positivity and the degree of damage to the bursa of Fabricius were assessed at day 10 and 17 post vaccination. The most frequently used index of the vaccination virus virulence is the relative weight of the FB (Mazarieg os et al. 1990).

The results of the present study seem to corroborate reports about variable virulence of vaccines classified as the so-called intermediate vaccines by manufacturers. A similar situation probably exists among virulent vaccines (see our results with vaccine $G$ ).

Of the mild vaccines, only vaccine A was able to produce sufficiently high antibodies titres and $100 \%$ positivity in the flock. Compared with other vaccines, the intermediate vaccine D produced only minimum positivity and a negative average titre compared with other vaccines at day 10 post vaccination. Virulent vaccines E, F and G produced almost 100\% positivity as well as high titres of post vaccination antibodies.

Vaccination virus virulence tests showed that vaccine $C$ included in the mild vaccine group was more pathogenic for the bursa of Fabricius than the remaining two mild vaccines. The vaccine $\mathrm{D}$, one of the intermediate vaccines, caused no major damage to the BF. From the practical point of view, test results of vaccine $\mathrm{D}$, which was broadly and successfully used in the Czech Republic in the period of IBD epizootic in the 1990s, are rather surprising. The success of the vaccine in the field is at variance with the low positivity and average antibodies titre found in the present study at day 10 post vaccination when chickens were 24 days old, notwithstanding the improvement at day 17 post vaccination, i.e. when the 
chickens were 31 days old. The difference may be explained by the fact that different types of chickens were vaccinated: while field experience was based on vaccination of meat birds, the present study used Leghorn chickens. Because testing of IBDV vaccination strains was performed in the absence of IBDV antibodies in experimental birds, we may hypothesize that differences in metabolism in the two types of chickens may have affected the humoral reaction of the birds following the vaccination.

Vaccines $\mathrm{E}$ and $\mathrm{F}$ were among virulent vaccines and, as expected, demonstrated high pathogenicity. Vaccine $\mathrm{G}$, on the other hand, although included among virulent vaccines, caused surprisingly no damage to the BF and had the best immunogenic properties.

Winterfield and Thacker (1978) tested immunogenicity and virulence of 8 intermediate vaccination strains against IBD and found considerable differences among the strains. Two of the strains were highly virulent, produced clinical symptoms, caused damage to BF and even death of birds. Similar results were reported by Naqi et al. (1980). Muskett et al. (1979) studied the properties of two live IBD vaccines on susceptible chickens and observed major damage to the bursa of Fabricius caused by one of them. According to Edwards et al. (1982), immunosuppression may last up to 4 weeks following vaccination.

Interesting results were reported by Mazarie g os et al. (1990), who studied six commercial vaccines against IBD designated as intermediate by their producers. Using the bursa of Fabricius index, the authors classified two of the vaccines as highly virulent, two as intermediate and the remaining two as mild.

The above facts cast doubt on the division of vaccines according to their virulence based on company information. This conclusion has been corroborated by Jackwood and Jackwood (1997), who classified the vaccination virus of vaccine D (S706) among mild IBD viruses on the basis of a genetic analysis of its nucleic acid.

If we accept the premise that virulent vaccines are not suitable for field use in areas free of highly virulent strains of the virus, then vaccine A seems to offer the optimum parameters of the vaccines tested in the present study. It was the only vaccine of the mild and intermediate vaccines that produced $100 \%$ positivity and a sufficiently high average titre of post vaccination antibodies within 10 days following vaccination.

These results are in accord with the findings by Černík (1982), who observed high levels of neutralizing antibodies at titres of 1:4400 to 1:10000 in flocks reared for egg production in 3 and 5 weeks after vaccination with vaccine $A$.

\section{Vliv vakcinačních kmenů infekční burzitidy na imunitní systém u kuřat nosného typu}

Výskyt infekční burzitidy kuřat v chovech kura domácího v České republice a problémy související s tímto onemocněním nás přivedly ke studiu imunoprofylaxe této choroby. Hladinu postvakcinačních protilátek proti infekční burzitidě jsme sledovali ELISA testem v sedmi pokusech u kuřat nosného typu bez mateřských protilátek. Kuřata byla vakcinována sedmi komerčními různě virulentními vakcínami (A, B, C - mírné; D - intermediální; $\mathrm{E}, \mathrm{F}$, $\mathrm{G}$ - horké). Pomocí indexu Fabriciovy burzy byl hodnocen vliv vakcinačních kmenů na imunitní systém kuřat a výsledky byly statisticky porovnány s kontrolní skupinou.

Zjistili jsme, že dostatečně vysoký titr protilátek a $100 \%$ pozitivitu hejna zajistila ze skupiny mírných vakcín pouze vakcína A. Naopak vakcína C způsobovala statisticky významnou atrofii Fabriciovy burzy. Intermediální vakcína D vykazovala pouze $80 \%$ pozitivitu, nejnižší průměrný titr postvakcinačních protilátek a zjištěný index Fabriciovy burzy byl statisticky nevýznamný. Horké vakcíny E a F vykazovaly téměř $100 \%$ pozitivitu i vysoké titry postvakcinačních protilátek a dle očekávání statisticky významnou atrofii Fabriciovy burzy. Vakcína G řazená mezi horké vakcíny dosáhla také 100\% pozitivity, ale překvapivě nepoškozovala Fabriciovu burzu. 
Zjištěné výsledky upozorňují na různou virulenci vakcinačních kmenů v rámci jednotlivých skupin i odlišné imunogenní schopnosti, se kterými je třeba počítat v běžné veterinární praxi.

\section{References}

BROWN, F 1986: The classification and nomenclature of viruses: Summary of results of meetings of the International Committee on Taxonomy of Viruses in Sendai. Intervirology 141-143

ČERNÍK, K 1982: Vývoj zamořenosti velkochovů drůbeže v ČSSR virovými infekcemi a mykoplazmózou během pěti let. Immunoprofilaxia 1: 6-26

EDWARDS, KR, MUSKETT, KC, THORNTON, DH 1982: Duration of imunosuppression caused by a vaccine strain of infectious bursal disease virus. ResVet Sci 32: 79-83

JACKWOOD, DJ, SAIF, YM, HUGHES, JH 1984: Nucleic acid and structural proteins of infectious bursal disease virus isolates belonging to serotypes I and II. Avian Dis 28: 990-1006

JACKWOOD, DJ, JACKWOOD, RJ 1997: Molecular identification of infectious bursal disease virus strains. Avian Dis 41: 97-104

JURANOVÁ R, NGUYEN THI NGA, KULÍKOVÁ, L, JURAJDA, V 2001: Pathogenicity of Czech isolates of infectious bursal disease virus. Acta Vet. Brno 70: 425-431

LUCIO, B, HITCHNER SB 1979: Infectious bursal disease emulsified vaccine: Effect upon neutralizing-antibody levels in the dam and subsequent protection of the progeny. Avian Dis. 23: 466-478

LUKERT, PD, SAYF, YM 1997: Infectious bursal disease. In: Diseases of poultry, 10th ed. B. W. Calnek, ed. Iowa State University Press, Ames, IA. pp. 721-738

MAZARIEGOS, LA, LUKERT, PD, BROWN, J 1990: Pathogenicity and immunosuppressive properties of infectious bursal disease ,intermediate“ strains. Avian Dis. 34: 203-208

MUSKETT, JC, HOPKINS IG, EDWARDS, KR, THORNTON, DH 1979: Comparison of two infectious bursal disease vaccine strains: efficacy and potential hazards in and maternally immune birds. Vet Rec 4: 332-334

NAQI, SA, MILLAR, DL, GRUMBLES, LC 1980: An evaluation of three commercially avaiable infectious bursal disease vaccines. Avian Dis 24: 233-241

NUNOYA, T, OTAKI Y, HIRAGA, M, SAITO, T 1992: Occurrence of acute infectious bursal disease with high mortality in Japan and pathogenicity of field isolates in specific-pathogen-free chickens. Avian Dis 36: 597-609

POSPÍŠILOVÁ, D, ELIÂŠ, D, BAJOVÁ, V 1999: Adenovirové a reovirové infekcie u hydiny. Semináŕ „Zdravotní problematika v chovech drůbeže,, Brno, p. 24

TSUKAMOTO, K, TANIMURA, N, KAKITA, S, OTA, K, MASE, M, IMAI, K, HIHARA, H 1995: Efficacy of three live vaccines against highly virulent infectious bursal disease virus in chickens with or without maternal antibodies. Avian Dis 39: 218-229

WINTERFIELD, RW, THACKER, HI 1978: Immune-response and pathogenicity of different strains of infectious bursal disease virus applied as vaccines. Avian Dis 22: 721-731 